\title{
The Role of Superoxide Anion and Hydrogen Peroxide in Phagocytosis-Associated Oxidative Metabolic Reactions
}

\author{
Robert L. Baehner, Suzanne K. Murrmann, Jacqueline Davis, and \\ RichaRd B. JOHNSTON, JR. \\ From the Department of Pediatrics, Indiana University School of Medicine, \\ Indianapolis, Indiana 46202 and University of Alabama in Birmingham, \\ Birmingham, Alabama 35233 and the Division of Hematology-Oncology, \\ James Whitcomb Riley Hospital for Children, Indianapolis, Indiana 46202
}

A B S T R A C T The contribution of hydrogen peroxide $\left(\mathrm{H}_{2} \mathrm{O}_{2}\right)$ and one of its unstable intermediates, superoxide anion $\left(\mathrm{O}_{\overline{2}}^{\overline{2}}\right)$, to the oxidative reactions that occur in phagocytizing leukocytes was explored by depleting these cells of $\mathrm{O}_{\dot{2}}^{-}$. This was accomplished by allowing them to phagocytize latex particles coated with superoxide dismutase (SOD), which catalyzes the generation of $\mathrm{H}_{2} \mathrm{O}_{2}$ from $\mathrm{O}_{\dot{2}}^{-}$. Although the rate and extent of phagocytosis of latex coated with bovine serum albumin was similar to latex coated with SOD, the rate of oxygen consumption, $\left[{ }^{14} \mathrm{C}\right]$ formate oxidation, $\left[1-{ }^{14} \mathrm{C}\right]$ glucose oxidation, and iodination of zymosan particles was significantly enhanced by SOD. In contrast, the rate and extent of reduction of nitroblue tetrazolium (NBT) was diminished by $60 \%$. These studies indicate that the majority of NBT reduction by leukocytes is due to $\mathrm{O}_{\overline{2}}^{\overline{2}}$, whereas stimulation of the hexose monophosphate shunt and iodination of ingested particles requires $\mathrm{H}_{2} \mathrm{O}_{2}$ generated from the increased reduction of oxygen by phagocytizing leukocytes.

\section{INTRODUCTION}

A series of oxidation-reduction reactions takes place in vitro in phagocytizing leukocytes, including: (a) a cyanide-insensitive burst of oxygen consumption; (b) production of $\mathrm{H}_{2} \mathrm{O}_{2} ;$; c ) stimulation of glucose oxidation through the hexose monophosphate shunt $(1,2)$; $(d)$ iodination of ingested particles ( 3$)$; and (e) reduction of nitroblue tetrazolium to insoluble formazan (4). Two cyanide insensitive oxidases, NADH and NADPH

Presented in part at the 15th Annual Meeting of the American Society of Hematology, 7-9 December 1974, Atlanta, Ga.

Received for publication 16 October 1974 and in revised form 18 April 1975.

The Journal of Clinical Investigation Volume 56 September 1975·571-576 oxidase, have been identified in leukocytes and each has received consideration as the primary oxidase mediating these reactions $(5,6)$. Recent studies confirm that several highly reactive unstable intermediate products of oxygen reduction, including superoxide anion $\left(\mathrm{O}_{\dot{2}}^{-}\right)^{1}$ are generated by human leukocytes during phagocytosis $(7-10)$. In a chemical system, $\mathrm{O}_{\dot{2}}$, generated by an oxidase-catalyzed reaction, can be assayed by observing the extent of inhibition of the reduction of nitroblue tetrazolium (NBT) or ferricy tochrome $c$ by superoxide dismutase (SOD) (11). This enzyme catalyzes the dismutation of $2 \mathrm{~mol}$ of $\mathrm{O}_{\overline{2}}^{\overline{2}}$ to form $1 \mathrm{~mol}$ of oxygen and $1 \mathrm{~mol}$ of $\left(\mathrm{H}_{2} \mathrm{O}_{2}\right)$.

Johnston et al. have observed diminished phagocytic bacterial killing when SOD, in distinction to bovine serum albumin (BSA) or denatured SOD, was present in the reaction mixture (10). The effect was markedly enhanced if the enzyme was associated with latex particles. It seemed possible that this technique might offer a unique means of depleting phagocytizing leukocytes of $\mathrm{O}_{\overline{2}}$ and simultaneously enhancing the rate of generation of $\mathrm{H}_{2} \mathrm{O}_{2}$. That is, if dismutation of the $\mathrm{O}_{2}^{-}$radical to $\mathrm{H}_{2} \mathrm{O}_{2}$ occurs within the phagocyte, as it does in chemical systems, it would seem likely that the following sequence of metabolic reactions occurs in leukocytes phagocytizing latex coated with SOD :

$2 \mathrm{O}_{2}+2 \mathrm{H} \cdot \stackrel{\text { Oxidase }}{\longrightarrow} \mathrm{O}_{\overline{2}}+\mathrm{O}_{\overline{2}}^{-}+2 \mathrm{H}^{+} \stackrel{\text { sOD }}{\longrightarrow} \mathrm{H}_{2} \mathrm{O}_{2}+\mathrm{O}_{2}$

Assuming that the oxidase-catalyzed reaction is not limiting in this system, as $\mathrm{O}_{\overline{2}}^{-}$is generated it would be

1 Abbreviations used in this paper: BSA, bovine serum albumin; NBT, nitroblue tetrazolium; $\mathrm{O}_{\dot{\overline{2}}}^{-}$, superoxide anion; SOD, superoxide dismutase. 
rapidly converted to $\mathrm{H}_{2} \mathrm{O}_{2}$ and oxygen. Therefore, those metabolic reactions dependent upon superoxide would be depressed by introduction of SOD into the cells, whereas those reactions dependent upon $\mathrm{H}_{2} \mathrm{O}_{2}$ would be enhanced. We have explored the metabolic effects of introducing latex-associated SOD into phagocytes. Results suggest that the phagocytic reduction of NBT is $\mathrm{O}_{\overline{2}}$ dependent, whereas stimulation of the hexose monophosphate shunt, stimulation of formate oxidation, and iodination of ingested particles are dependent upon $\mathrm{H}_{2} \mathrm{O}_{2}$ generation.

\section{METHODS}

Collection and preparation of leukocyte suspension. Peripheral blood was collected in heparinized plastic syringes from normal young adult volunteers. After mixing with 1-2 ml Plasmagel (HTI Corp., Associated Biomedic Systems, Inc. Buffalo, N. Y.), the syringe was inverted and erythrocytes were allowed to sediment at $25^{\circ} \mathrm{C}$ for $30 \mathrm{~min}$. The supernatant leukocyte-rich plasma was decanted into $60 \mathrm{ml}$ plastic, conical centrifuge tubes and mixed with 3 vol of $0.87 \% \mathrm{NH}_{4} \mathrm{Cl}$ for $5 \mathrm{~min}$ to remove the red cells. This mixture was centrifuged at $800 \mathrm{~g}$ for $5 \mathrm{~min}$ to obtain a purified white cell pellet, which was washed three times with Krebs-Ringer phosphate buffer $(\mathrm{pH}$ 7.4) enriched with $10 \mathrm{mM}$ glucose. Leukocyte and differential counts were performed on these suspensions to obtain the absolute number of granulocytes; the preparations contained $85-90 \%$ granulocytes.

Coating of latex particles. Latex particles measuring 0.81 $\mu \mathrm{m}$ in diameter (Dow Chemical Co., Midland, Mich.) were dialyzed against distilled water at $4^{\circ} \mathrm{C}$ overnight. Particles were coated with either SOD (Truett Labs., Dallas, Tex. or purified by the method of McCord and Fridovich [12]) or BSA (Sigma Chemical Co., St. Louis, Mo.) by incubation with these proteins at a concentration of $1 \mathrm{mg}$ per $1 \mathrm{ml}$ of undiluted latex particles at $25^{\circ} \mathrm{C}$ in $25-\mathrm{ml}$ siliconized glass Erlenmeyer flasks for $15 \mathrm{~min}$ (12). Coating of latex with apodismutase, hemoglobin, and thrombin was performed in the same way. To determine the extent of protein binding to latex, after incubation the latex particles were centrifuged, the supernate was discarded, and the amount of protein associated with the particles was determined by the method of Lowry, Rosebrough, Farr, and Randall (13). To ensure that SOD associated with latex was enzymatically active, $0.1 \mathrm{ml}$ of coated latex was assayed for SOD activity by the inhibition of cytochrome $c$ reduction with xanthine and xanthine oxidase (12). Apodismutase was prepared by the method of McCord and Fridovich (12) and was assayed for SOD activity before incubation with latex.

Rate of uptake of latex by leukocytes. A suspension of $5 \times 10^{7}$ granulocytes in a volume of $1.6 \mathrm{ml}$ was added to $0.4 \mathrm{ml}$ latex-protein suspension and incubated in triplicate in $25-\mathrm{ml}$ siliconized Erlenmeyer flasks at $37^{\circ} \mathrm{C}$ in a Dubnoff metabolic shaker. Aliquots of $0.5 \mathrm{ml}$ were taken at $0,5,15$, and $30 \mathrm{~min}$ of incubation and placed in siliconized glass test tubes containing $10 \mathrm{ml}$ ice-cold saline. The tubes were then centrifuged at $300 \mathrm{~g}$ for $5 \mathrm{~min}$ at $4^{\circ} \mathrm{C}$ and washed twice in ice-cold saline. The cell pellets were then placed in a $100^{\circ} \mathrm{C}$ oven overnight to ensure complete drying. Then $2 \mathrm{ml} \rho$-dioxane (Matheson Coleman \& Bell, Matheson Scientific, Inc., East Rutherford, N. J.) at approximately $60^{\circ} \mathrm{C}$ was added to each dry button and allowed to stand at $25^{\circ} \mathrm{C}$ for $2 \mathrm{~h}$ until the cell pellet was dissolved. This solution was stirred occasionally to complete solubility of the pellet. Samples were cleared by centrifugation at $300 \mathrm{~g}$ for $5 \mathrm{~min}$ and then read on a Gilford Spectrophotometer (Gilford Instrument Laboratories, Inc., Oberlin, Ohio) at $253 \mathrm{~nm}$ against a $\rho$-dioxane blank. Appropriate blanks containing latex-BSA or latex-SOD without cells, and samples containing cells without latex were run in triplicate at each time point. The combined blank values accounted for less than $10 \%$ of the cell values at each time point.

\section{Metabolic reactions of leukocytes}

Oxygen consumption. The oxygen consumption by phagocytes ingesting latex coated with BSA or SOD was measured with a Clark membrane oxygen electrode (Yellow Springs Instrument Co., Yellow Springs, Ohio) using an expanded scale Varian recorder (Varian Associates, Palo Alto, Calif.) calibrated so that a change of $60 \%$ oxygen saturation of the incubate produced a full-scale deflection. Additional experiments were performed using latex coated either with apodismutase, hemoglobin, or thrombin. A 1-ml suspension of phagocytes at a concentration of $2.0 \times 10^{7}$ cells $/ \mathrm{ml}$ was placed in the reaction vessel and $1.9 \mathrm{ml}$ of Krebs-Ringer phosphate glucose buffer was added. After a 5 -min incubation at $37^{\circ} \mathrm{C}$, $0.1 \mathrm{ml}$ suspension of protein-coated latex was added, and the respiratory burst was followed. After a 1-min period of equilibration, the increased rate of oxygen consumption was linear for at least $10 \mathrm{~min}$. Results were expressed as $\mu \mathrm{l} \mathrm{O}_{2} / \mathrm{h}$ per $10^{7}$ phagocytes calculated from the linear slopes produced. Studies in the presence of NBT were performed with $0.1-\mathrm{ml}$ of undiluted plain latex particles or $0.1 \mathrm{ml}$ of a $5 \%$ suspension of zymosan (Nutritional Biochemicals Corp., Cleveland, Ohio) previously opsonized by incubating with $10 \%$ (vol/vol) fresh serum at $25^{\circ} \mathrm{C}$ for $30 \mathrm{~min} ; 0.1 \mathrm{ml}$ of a $0.2 \%$ solution of NBT was added to both preparations. Each experiment was done in triplicate.

$\left.{ }^{[4} \mathrm{C}\right]$ Formate and $\left[1{ }^{14} \mathrm{C}\right]$ glucose oxidation. The rates of $\left[{ }^{14} \mathrm{C}\right]$ formate and $\left[1-{ }^{14} \mathrm{C}\right]$ glucose oxidation were determined by a previously described method (14). Preliminary studies using 10-min intervals established that the rates were linear for at least $30 \mathrm{~min}$ with latex alone or latex coated with either BSA or SOD. To ensure that the metabolic responses observed were due to $\mathrm{H}_{2} \mathrm{O}_{2}$ produced by SOD and not to nonspecific effects of this enzyme, a series of $\left[1-{ }^{14} \mathrm{C}\right]$ glucose oxidation experiments were performed using apodismutase, hemoglobin, and thrombin proteins with and without latex particles. To further elucidate the role of $\mathrm{H}_{2} \mathrm{O}_{2},\left[1-^{14} \mathrm{C}\right]$ glucose oxidation experiments were performed on leukocytes ingesting latexSOD to which was added $4.6 \mathrm{U}$ of catalase. Other experiments were performed on leukocytes incubated with a mixture of latex-BSA $(90 \%)$ and latex-SOD $(10 \%)$.

Quantitative iodination of zymosan particles. The influence on iodination of ingested opsonized zymosan particles by latex coated with BSA or SOD was measured at $0,15,30$, and 60 min according to the method of Pincus and Klebanoff (15).

Reduction of NBT. NBT reduction was measured as previously described (4). $0.1 \mathrm{mg}$ SOD or $0.1 \mathrm{mg}$ of BSA was added directly to both resting and phagocytic flasks; latex was added to the phagocytizing samples to begin the experiments.

\section{RESULTS}

Quantitation of BSA or SOD bound to latex particles. When $1 \mathrm{mg}$ BSA was incubated with $1.0 \mathrm{ml}$ undiluted suspension of latex particles, $33 \%$ of the total weight of the protein (i.e., $0.33 \mathrm{mg}$ or $5.50 \mathrm{nmol}$ ) was bound. $18 \%$ of SOD and apodismutase was absorbed to the latex $(0.18 \mathrm{mg}$ or $5.45 \mathrm{nmol})$. The latex-coated SOD exhibited $20 \%$ of the total SOD activity. 


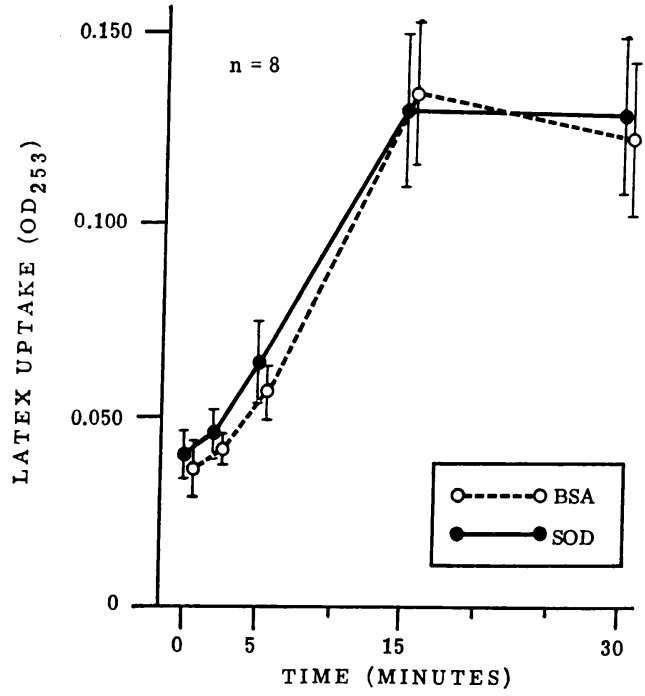

FIGURE 1 Rate and extent of uptake of latex particles by granulocytes. Each point represents the mean of triplicate samples of eight separate studies. The bars represent the SEM. BSA means bovine serum albumin and SOD means superoxide dismutase; either protein was preincubated with undiluted previously dialyzed $0.81-\mu \mathrm{m}$ latex particles. See text for further details.

Rate of uptake of latex by granulocytes. The rate of uptake of latex by granulocytes determined by the spectrophotometric method was linear from 5 to $15 \mathrm{~min}$ during the $30-\mathrm{min}$ incubation period. As indicated in Fig. 1, there was no significant difference in the quantity of either type of latex particle phagocytized or in the rate of this phagocytosis by granulocytes at each time point tested $(P>0.05, t$ test). Maximum uptake of particles was evident by $15 \mathrm{~min}$.

Metabolic studies. The rate of oxygen consumption by leukocytes at rest and during phagocytosis of latex coated with BSA or SOD is given in Table I. There was a significant increase in oxygen consumption observed when latex coated with either protein was ingested. However, the rate of oxygen consumption in the

\section{TABLE I}

Rate of Oxygen Consumption by Leukocytes at Rest and during Phagocytosis of Latex Particles Coated with SOD and BSA

\begin{tabular}{|c|c|c|}
\hline $\begin{array}{l}\text { Protein } \\
\text { added }\end{array}$ & Resting & Phagocytizing \\
\hline \multicolumn{3}{|c|}{ l $O_{2} / h / 10^{7}$ phagocytes* } \\
\hline BSA & $2.21 \pm 0.71$ & $4.15 \pm 1.08$ \\
\hline SOD & $2.41 \pm 0.90$ & $7.01 \pm 2.57 \ddagger$ \\
\hline
\end{tabular}

* Mean \pm SEM of duplicate values from eight experiments. $\ddagger$ Value is significantly different from all other values. $(P<0.001, t$ test $)$.
TABLE II

Rate of Oxygen Consumption by Phagocytizing Leukocytes during Reduction of NBT

\begin{tabular}{ccc}
\hline Conditions & NBT & $\mathrm{O}_{2}$ consumption \\
\hline & & $\begin{array}{c}\mu l / h / 10^{7} \\
\text { phagocytes* }\end{array}$ \\
Resting (6) & Absent & $1.92 \pm 0.14$ \\
Phagocytizing latex (6) & Absent & $9.83 \pm 1.39$ \\
Phagocytizing latex (6) & Present & $4.72 \pm 0.24 \ddagger$ \\
Phagocytizing zymosan (5) & Absent & $11.08 \pm 0.75$ \\
Phagocytizing zymosan (6) & Present & $6.02 \pm 0.94 \ddagger$ \\
\hline
\end{tabular}

* Mean \pm SEM. Values in parenthesis indicate number of experiments performed in duplicate.

$\ddagger$ Values are significantly different than corresponding value obtained without NBT $(P=0.001, t$ test $)$.

presence of latex coated with SOD was significantly greater than that observed with latex-BSA.

The addition of either type latex particle to the system devoid of cells did not evoke an alteration in oxygen consumption. In another series of experiments summarized in Table II, addition of NBT to leukocytes phagocytizing either latex or zymosan particles consistently produced a decrease in oxygen consumption which persisted for more than $15 \mathrm{~min}$ at $37^{\circ} \mathrm{C}$. This decrease was evident when NBT was added before or after the particles.

The stimulation of $\left[1-{ }^{14} \mathrm{C}\right]$ glucose oxidation to ${ }^{14} \mathrm{CO}_{2}$ was enhanced by latex coated with SOD when added to resting leukocy tes or to leukocy tes ingesting latex-BSA. As noted in Table III, leukocytes ingesting latex BSA

\section{TABLE III}

Rate of $\left[1{ }^{14} \mathrm{C}\right]$ Glucose Oxidation by Leukocytes at Rest and during Phagocytosis of Latex Particles Coated with SOD and BSA

\begin{tabular}{cc}
\hline & $\begin{array}{c}{\left[1-{ }^{-14}\right] \mathrm{Glucose} \rightarrow} \\
{ }^{4} \mathrm{CO}_{2} / 30 \mathrm{~min} / 10^{7} \\
\text { phagocytes* }\end{array}$ \\
\hline Resting & $\begin{array}{c}\text { nmol } \\
\text { Phagocytizing latex-BSA }\end{array}$ \\
Phagocytizing latex-SOD & $7.08 \pm 2.11$ \\
†Phagocytizing latex-SOD & $20.43 \pm 1.39$ \\
with added catalase & $7.61 \pm 2.03$ \\
†Phagocytizing latex-BSA & $19.03 \pm 3.50$ \\
+latex-SOD & \\
\hline
\end{tabular}

* Mean \pm SEM of duplicate values from eight experiments. The values for latex-BSA and latex-SOD + catalase are significantly different from the resting value and from the values for latex-SOD and latex-BSA + latex-SOD $(P<0.001$, $t$ test).

$\ddagger$ Mean \pm SEM of 12 determinations from three experiments. 
TABLE IV

Rate of $\left[{ }^{14} \mathrm{C}\right]$ Formate Oxidation by Leukocytes at Rest and during Phagocytosis of Latex Particles (oated with SOD and BSA

\begin{tabular}{lc}
\hline & $\begin{array}{c}{\left[{ }^{14} \mathrm{C}\right] \text { Formate } \rightarrow} \\
{ }^{14} \mathrm{CO}_{2} / 30 \mathrm{~min} / 10^{7} \\
\text { phagocytes* }\end{array}$ \\
\hline Resting & $\begin{array}{c}n m o l \\
\text { Phagocytizing latex-BSA }\end{array}$ \\
Phagocytizing latex-SOD & $1.36 \pm 0.03$ \\
& $1.87 \pm 0.04$ \\
\hline
\end{tabular}

* Mean \pm SEM of duplicate values from eight experiments. Each value is significantly different from the other two. $(P<0.001, t$ test $)$.

exhibited an almost threefold increase in hexose monophosphate shunt activity, whereas ingestion of latexSOD or a $10 \%$ mixture of latex-SOD to latex-BSA produced an eightfold increase. The addition of apodismutase, hemoglobin, or thrombin did not alter the hexose monophosphate shunt activity of resting leukocytes. Similar to BSA, a two- to threefold increase occurred when the leukocytes ingested latex coated with either of the three proteins. Also the stimulation of $\left[1-{ }^{14} \mathrm{C}\right]$ glucose oxidation was not observed in leukocytes to which catalase was added less than $1 \mathrm{~min}$ after latexSOD (Table III). There was a less striking yet significant increase in $\left[{ }^{14} \mathrm{C}\right]$ formate oxidation when leukocytes ingested latex-SOD compared to latex-BSA (Table IV).

Results of the quantitation of the rate of iodination of zymosan particles by phagocytizing leukocy tes simultaneously ingesting latex particles are given in Table $\mathrm{V}$. At each time interval during the 60 -min incubation, significantly geater iodination was observed in the presence of latex-SOD compared to latex-BSA. No iodination occurred when zymosan was omitted from the system. In contrast to the above responses, the presence of SOD with leukocytes at rest or during

TABLE V

Rate of Iodination of Zymosan Particles by Leukocytes Phagocytizing Latex Particles Coated with $S O D$ or $B S A$

\begin{tabular}{ccr}
\hline Time & \multicolumn{1}{c}{ BSA } & \multicolumn{1}{c}{ SOD } \\
\hline $\min$ & $c p m / 10^{7}$ & phagocytes* \\
0 & $81 \pm 20$ & $102 \pm 12 \ddagger$ \\
15 & $706 \pm 106$ & $1,059 \pm 129$ \\
30 & $1,423 \pm 136$ & $2,886 \pm 379$ \\
60 & $2,077 \pm 237$ & $4,063 \pm 404$ \\
\hline
\end{tabular}

* Mean \pm SEM of triplicate values from eight experiments. ¥ At each time point the values obtained in the presence of SOD were significantly higher than those with BSA $(P<0.001, t$ test $)$.
TABLE VI

Rate of NBT Reduction by Leukocyles Suspended in Either $0.1 \mathrm{mg} S O D$ or BSA at Rest and during Phagocytosis of Latex Particles.

\begin{tabular}{ccc}
\hline $\begin{array}{c}\text { Protein } \\
\text { added }\end{array}$ & Rest & Phagocytizing \\
\hline & \multicolumn{2}{c}{$O D_{515} / 15$} \\
min $/ 10^{7}$ cells* \\
BSA & $0.139 \pm 0.005$ & $0.337 \pm 0.018$ \\
SOD & $0.055 \pm 0.006$ & $0.129 \pm 0.012$ \\
\hline
\end{tabular}

* Mean \pm SEM of duplicate tubes from five experiments. Both resting and phagocytizing values were significantly less than corresponding values with BSA $(P<0.001, t$ test $)$.

phagocytosis of latex inhibited the reduction of $\mathrm{NBT}$ to formazan. This is evident in Table VI which indicates that NBT reduction in the presence of SOD was decreased by approximately $62 \%$ in comparison to reduction of $\mathrm{NBT}$ in the presence of $\mathrm{BSA}$.

\section{DISCUSSION}

These studies were designed to determine the contribution of $\mathrm{H}_{2} \mathrm{O}_{2}$ and its unstable intermediate $\mathrm{O}_{\dot{2}}$, to some well-known oxidative metabolic reactions of phagocytizing leukocytes. It is apparent from the studies of Babior, Kipnes, and Curnutte (7) and of Johnston et al. (10) that $\mathrm{O}_{\dot{2}}^{-}$is generated as a by-product of phagocytosis. The enzyme, SOD, catalyzes the conversion of $\mathrm{O}_{\overline{2}}$ to $\mathrm{H}_{2} \mathrm{O}_{2}$ and oxygen. The stoichiometry of these two related reactions is likely as follows:

$2 \mathrm{O}_{2}+2 \mathrm{H} \cdot \stackrel{\text { Oxidase }}{\longrightarrow} \mathrm{O}_{\overline{2}}^{-}+\mathrm{O}_{\dot{2}}^{-}+2 \mathrm{H}^{+} \stackrel{\text { soD }}{\longrightarrow} \mathrm{H}_{2} \mathrm{O}_{2}+\mathrm{O}_{2}$

These reactions would generate either equimolar $\mathrm{O}_{\dot{2}}$ for each mole of $\mathrm{O}_{2}$ consumed, or $1 \mathrm{~mol}$ each of $\mathrm{H}_{2} \mathrm{O}_{2}$ and $\mathrm{O}_{2}$ for every $2 \mathrm{~mol}$ of $\mathrm{O}_{2}$ consumed if the reaction goes to completion. In previous experiments with phagocytizing leukocytes, we and others could account for only $3-15 \%$ of the consumed oxygen as $\mathrm{H}_{2} \mathrm{O}_{2}$ available for oxidation of $\left[{ }^{14} \mathrm{C}\right]$ formate or reduced glutathione $(16,17)$.

The techniques utilized in these studies require that there is an equal rate of uptake of latex coated with SOD or BSA. Variable rates of uptake will influence the rates of oxidation-reduction reactions in leukocytes. In previous studies, we bound glucose oxidase to latex and restored defective oxidase activity in chronic granulomatous disease leukocytes which resulted in improved $\left[1-{ }^{14} \mathrm{C}\right]$ glucose oxidation and $\left[{ }^{14} \mathrm{C}\right]$ formate oxidation as well as improved intracellular bactericidal activity $(14,18)$. However, the rate of uptake of latex coated with enzyme by phagocytes was diminished compared to uncoated latex (14). As can be observed in this study, comparison of Table $I$ with rows 1 and 2 of Table II 
confirmed that protein bound to latex attenuated the normal particle-induced stimulation of oxygen consumption. Since the extent of these metabolic perturbations depends in part on the rate of particle uptake, proper interpretation of our studies demands that the rate and extent of uptake by leukocy tes of latex coated with SOD must equal that of latex coated with BSA. We found no differences in the initial rate of uptake of latex coated with either SOD or BSA or in the extent of ingestion of latex by leukocytes during a 30 -min incubation period. Thus, we believe the technique to be a reliable method of studying the influence of SOD on the oxidative metabolic reactions of phagocytizing leukocytes.

These studies focus on the altered rate of several oxidative reactions in phagocytizing leukocytes produced by introduction of SOD into the cell. The fact that the rate of oxygen consumption was enhanced threefold by SOD suggestes that the oxidase catalyzed reaction was not limiting in this system. Iyer, Islam, and Quastel (19) previously have shown that $\left[{ }^{14} \mathrm{C}\right]$ formate oxidation is dependent upon $\mathrm{H}_{2} \mathrm{O}_{2}$. Our finding of increased $\left[{ }^{14} \mathrm{C}\right]$ formate oxidation suggests that the rate of $\mathrm{H}_{2} \mathrm{O}_{2}$ production was increased by $\mathrm{SOD}$. The addition of catalase, which rapidly converts $\mathrm{H}_{2} \mathrm{O}_{2}$ to $\mathrm{O}_{2}$ and $\mathrm{H}_{2} \mathrm{O}$, inhibited the increase in $\left[1-{ }^{14} \mathrm{C}\right]$ glucose oxidation observed in these leukocytes ingesting latex-SOD. The increase in hexose monophosphate shunt activity and rate of iodination confirms that these two metabolic reactions are stimulated primarily by $\mathrm{H}_{2} \mathrm{O}_{2}$ rather than superoxide in phagocytizing leukocytes. In addition, the increase in $\mathrm{H}_{2} \mathrm{O}_{2}$ generated from $\mathrm{O}_{\overline{2}}^{\overline{2}}$ dismutation is linked with activation of the shunt, perhaps through the glutathione peroxidase pathway (20). which favors this mechanism as an explanation for shunt activation during phagocytosis (21).

The observation by Johnston and co-workers (10) that, under experimental conditions similar to those described here, intracellular microbicidal activity was consistently diminished suggests that $\mathrm{O}_{\dot{2}}^{-}$or its byproduct does play a role in bacterial killing and lends support to the concept that killing is not necessarily dependent upon iodination, as previously recognized (22).

The metabolic explanation for NBT reduction by phagocytizing leukocytes based upon our studies suggests two possible mechanisms. Since NBT is a redox dye with an oxidation-reduction potential of close to zero, it competes with oxygen for electrons and protons. This is apparent in those studies which showed a consistent decrease in oxygen consumption by phagocytizing leukocytes during NBT reduction to insoluble formazan. An alternative explanation for the diminished oxygen consumption observed during NBT reduction could involve the reaction of $\mathrm{O}_{\overline{2}}^{\overline{2}}$, formed in the univalent reduction of oxygen with $\mathrm{NBT}$. $\mathrm{O}_{\overline{2}}^{-}$can reduce $\mathrm{NBT}$ to formazan and oxygen is generated. In this way, NBT could also decrease the net consumption of oxygen in the system. Since NBT reduction was diminished $62 \%$ by $\mathrm{SOD}$, this indicates that $38 \%$ of the reduction of NBT is independent of oxygen, and perhaps involves membrane-associated reductases $(23,24)$. Since the redox potential of the $\mathrm{H}_{2} \mathrm{O}_{2}-\mathrm{O}_{\dot{2}}$ half-cell at $\mathrm{pH} 7.4$ is -0.98 , the reduction of $\mathrm{NBT}$ by $\mathrm{H}_{2} \mathrm{O}_{2}$ is not possible. Our studies, as well as those of Johnston et al. (10), show that SOD does decrease NBT reduction by about two-thirds, compared to the result observed during leukocyte ingestion of BSA-coated latex. Thus, it is likely that two metabolic reactions control NBT reduction in phagocytizing leukocytes: (a) a reductase which catalyzes the direct reduction of NBT independent of the univalent reduction of oxygen to superoxide anion; and $(b)$ an oxidase which endows oxygen with an extra electron that can be displaced for the reduction of ferricytochrome $c$ or NBT. These quantitative studies support the idea that the majority of NBT reduction by phagocytizing leukocytes is mediated by the latter reaction through the generation of $\mathrm{O}_{\dot{2}}$.

\section{ACKNOWLEDGMENTS}

This work was supported by the U. S. Public Health Service grants AI-10892, CA-13890, AI-10286, CA-13148, and a grant from the Riley Memorial Association.

\section{REFERENCES}

1. Karnovsky, M. L. 1962. Metabolic basis of phagocytic activity. Phy'siol. Rev. 42: 143-168.

2. Karnovsky, M. L. 1968. The metabolism of leukocytes. Semin. Hematol. 5 : 156-165.

3. Klebanoff, S. J. 1967. A peroxidase-mediated antimicrobial system in leukocytes. J. Clin. Invest. 46: 1078. (Abstr.)

4. Baehner, R. L., and D. G. Nathan. 1968. Quantitative nitroblue tetrazolium test in chronic granulomatous disease. N. Engl. J. Med. 278: 971-976.

5. Baehner, R. L., N. Gilman, and M. L. Karnovsky. 1970. Respiration and glucose oxidation in human and guinea pig leukocytes: comparative studies. J. Clin. Invest. 49: 692-700.

6 Zatti, M., and F. Rossi. 1966. Mechanism of the respiratory stimulation in phagocytizing leukocytes. The $\mathrm{KCN}$-insensitive oxidation of $\mathrm{NADPH}_{2}$. Experientia (Basel). $22:$ 758-759.

7. Babior, B. M., R. S. Kipnes, and J. T. Curnutte. 1973. Biological defense mechanisms. The production by leukocytes of superoxide, a potential bactericidal agent. $J$. Clin. Invest. 52 : 741-744.

8. Allen, R. C., R. L. Stjernholm, and R. H. Steele. 1972. Evidence for the generation of an electronic excitation state(s) in human polymorphonuclear leukocytes and its participation in bactericidal activity. Biochem. Biophys. Res. Commun. 47: 679-684.

9. Webb, L. S., B. B. Keele, Jr., and R. B. Johnston, Jr. 1974. Inhibition of phagocytosis-associated chemiluminescence by superoxide dismutase. Infect. Immun. 9: 1051-1056. 
10. Johnston, R. B., Jr., B. B. Keele, Jr., H. P. Misra, J. E. Lehmeyer, L. S. Webb, R. L. Baehner, and K. V. Rajagopalan. 1975. The role of superoxide anion generation in phagocytic bactericidal activity. Studies with normal and chronic granulomatous disease leukocytes. J. Clin. Invest. 55: 1357-1372.

11. Fridovich, I. 1972. Superoxide radical and superoxide dismutase. Accounts Chem. Res. 5: 321-326.

12. McCord, J. M., and I. Fridovich. 1969. Superoxide dismutase. An enzymic function for erythrocuprein (hemocuprein). J. Biol. Chem. 244: 6049-6055.

13. Lowry, O. H., N. J. Rosebrough, A. L. Farr, and R. J. Randall. 1951. Protein measurements with the Folin phenol reagent. J. Biol. Chem. 193: 265-275.

14. Baehner, R. L., D. G. Nathan, and M. L. Karnovsky. 1970. Correction of metabolic deficiencies in the leukocytes of patients with chronic granulomatous disease. J. Clin. Invest. 49: 865-870.

15. Pincus, S. H., and S. J. Klebanoff. 1971. Quantitative leukocyte iodination. N. Engl. J. Med. 284: 744-750.

16. Baehner, R. L., D. G. Nathan, and W. B. Castle. 1971. Oxidant injury of caucasian glucose-6-phosphate dehydrogenase-deficient red blood cells by phagocytizing leukocytes during infection. J. Clin. Invest. 50: 24662473.

17. Paul, B., and A. J. Sbarra. 1968. The role of the phago- cyte in host-parasite interactions. XIII. The direct quantitative estimation of $\mathrm{H}_{2} \mathrm{O}_{2}$ in phagocytizing cells. Biochim. Biophys. Acta. 156: 168-178.

18. Johnston, R. B., Jr., and R. L. Baehner. 1970. Improvement of leukocyte bactericidal activity in chronic granulomatous disease. Blood J. Hematol. 35: 350-355.

19. Iyer, G. Y. N., D. M. F. Islam, and J. H. Quastel. 1961. Biochemical aspects of phagocytosis. Nature (Lond.). 192 : 535-541.

20. Reed, P. W. 1969. Glutathione and the hexose monophosphate shunt in phagocytizing and hydrogen peroxide-treated rat leukocytes. J. Biol. Chem. 244: 24592464.

21. Karnovsky, M. L. 1973. Chronic granulomatous diseasepieces of a cellular and molecular puzzle. Fed. Proc. 32: $1527-1533$.

22. Klebanoff, S. J., and C. B. Hamon. 1972. Role of myeloperoxidase-mediated antimicrobial systems in intact leukocytes. J. Reticuloendothel. Soc. 12: 170-196.

23. Briggs, R. T., D. B. Drath, M. J. Karnovsky, and M. L. Karnovsky. 1974. Surface localization of NADH oxidase in polymorphonuclear leucocytes. J. Cell Biol. 63: 36a. (Abstr.)

24. Baehner, R. L. 1975. Subcellular distribution of nitroblue tetrazolium reductase (NBT-R) in human polymorphonuclear leukocytes (PMN). J. Lab. Clin. Med. In press. 